\title{
Evaluation of Employers' Perceptions of the Role of Guidance and Counselling and Vocational Education in Sustainable Development in Nigeria
}

\author{
Comfort W. Agi, Ph.D. \\ Department of Educational Foundations \\ Rivers State University of Science and Technology \\ Port Harcourt
}

Doi:10.5901/mjss.2013.v4n4p461

\begin{abstract}
Guidance and Counselling and vocational education have long been recognized as a major vehicle for national development and growth. This study was aimed at evaluating the opinions of employers of labour on the roles of guidance and Counselling and vocational education in sustainable development in Nigeria. The sample comprised of 80 indigenous and 68 multi-national employers in the south-south geopolitical zone of Nigeria. Two research questions and two null hypotheses guided the study. A duly validated questionnaire was used for data collection. Data were analysed using statistical mean and standard deviation to answer the research questions, while t-test statistics was used to test the hypotheses. The findings revealed among other things that employers were not satisfied with the contribution of guidance and Counselling and vocational education to sustainable development in Nigeria. Based on the findings, it was recommended that government of Nigeria should provide effective leadership and partner with private sector in order to place guidance and Counselling and vocational education in its rightful position in sustainable development.
\end{abstract}

Keywords: Perception, sustainable development, guidance and counselling, vocational education.

\section{Introduction}

The economic competitiveness of a country depends on the skills of its workers, and the skills and competencies of the workforce, in turn, are dependent upon the quality of the country's education and training systems (Denga and Akinboye, 2002). Aina (2006) posits that education is indisputably recognised as the bedrock of any meaningful development, while guidance and Counselling and vocational education is the cornerstone for any sustainable technological development programme. Thus, guidance and Counselling and vocational education is regarded globally as a springboard to socioeconomic growth and technological development.

Guidance and Counselling and vocational education in Nigeria is perceived to be greatest weapons that can be used to achieve desirable changes and development of the nation. It is in line with this that Nigeria's current educational system otherwise referred as 6-3-3-4 educational system emphasized guidance and Counselling and vocational education as launching pad of the country into technology age. The Federal Republic of Nigeria (2004:29) in the National Policy on Education defined guidance and Counselling and vocational education as:

Referring to those aspects of the educational process involving in addition, to general education, the study of technologies and related sciences and the acquisition of practical skills, attitudes, understanding and knowledge relating to occupations in various sectors of economic and social life.

This form of education is deliberately designed to help man improve his skills. It places emphasis on skill development of the individuals in chosen occupation (Olaitan, 1993).

According to Ezeji (2005:6), Nigeria's National Master-plan (Blue print) for guidance and Counselling and vocational education explained the objectives of formal guidance and Counselling and vocational education to include:

1. Pre-vocational education in primary and secondary schools for general technological awareness, acquisition of technical literary and general technical versality;

2. Vocational education in job specific vocational schools for the production of craftsmen level manpower; 
3. Vocational education in polytechnic institutions for he production of technician/technologist level; and professional education in university level institutions for the production of manpower at professional level.

4. Professional education in university level institutions for the production of manpower at professional level.

There are also non-formal and informal types of guidance and Counselling and vocational education besides the formal type in Nigeria. The former two types are conducted outside the school system and their graduates are not considered in this study.

Guidance and Counselling and vocational education therefore, has an important role to play in raising the quality of work and quality of its graduates, increasing job satisfaction and motivating workers as well as enhancing productivity (Manfred \& Jennifer, 2004). In the new economic development therefore, Guidance and Counselling and vocational education is expected to produce an educated, skilled and motivated workforce for sustainable development and nation's growth.

The concept of sustainable development has been defined in many widely differing ways. One of such broadly accepted definition is that of Brundtland commission report in 1987, which defined sustainable development as "a new form of development perspective which integrates the production process with resources conservation and environmental enhancement; it should meet the need of the present without compromising our ability to meet those of the future" (World Commission on Environment and Development (WCED) (1987:1). In the same vein, the Food and Agricultural Organization (FAO) (1988) defined sustainable development as the management and conservation of the natural resources base and the orientation of technological and institutional change in such a manner as to ensure the attainment and continued satisfaction of human needs for present and future generation.

Arokoyu (2004) viewed sustainable development as inherently a value-laden concept, in that it implies responsibility for both present and future generation. Succinctly, sustainable development is a development through the use of all resources and the creation of society in which people have the opportunities to succeed considering public wealth and economic good (Nnodim, et al, 2006). Sustainable development is therefore a continuous and progressive increase and expansion of the volume of goods and services provided in a given economy with improvement in the social, political and economic life of present as well as future generation (Kurya and Hassan, 2007).

In essence, sustainable development is about the development of individuals and that of the economy. In this regard, Guidance and Counselling and vocational education is viewed as an indispensable instrument for sustainable development because Guidance and Counselling and vocational education empowerment improves a nation's economy, provides job opportunities, reduces crime rates and encourages creativity and competitiveness in nation building. Guidance and Counselling and vocational education facilitates the adjustment of the skills and knowledge of man to the changing demands within the society. Skill and knowledge as well as social values acquired through Guidance and Counselling and vocational education allow an individual to manipulate the natural and physical environment for making life more useful for improved sustainable scientific, technological and economic development. Through Guidance and Counselling and Vocational Education, goods and services are easily available thus, giving rise to high standard of living among the citizens of a nation. No doubt, Guidance and Counselling and Vocational education is a veritable tool that cannot be ignored as it equips individuals with necessary skills for sustainable development of a nation.

The socio-economic changes currently taking place worldwide pose challenges to many nations. This trend has given rise to economic, political and social crises that are threatening the political and economic stability of some nations. In this regard, Giroux (1991) states that the rising unemployment, lack of skilled workers, high dropout rates and the changing demographic nature of the workforce have placed the issue of workforce education high on the educational reform agenda of many nations. In line with this view, Okolocha (2006) observed that the massive rate or unemployment and the changing face of the economic, social, and political and labour market worldwide have led to new education reforms/policies with emphasis on Guidance and Counselling and Vocational education geared towards helping people to be self-reliant.

It is in recognition of the changing role of Guidance and Counselling and Vocational education in the world's economic order that different countries have come up with different frameworks towards repositioning their Guidance and Counselling and Vocational education programmes. According to Micheal (2002), the French National Assembly enacted a law on social modernization which contains important measures concerning Guidance and Counselling and Vocational education and the right to employment. Micheal further reported that the government of Denmark made efforts to increase the number of training places with emphasis on social and practical skills development. In Germany, use of the objectives of the country's education reform is to promote the vocational education of gifted young people and to raise the standard of Guidance and Counselling and Vocational Education s (Micheal, 2002). 
In Kenya, the 8-4-4 educational system was introduced with emphasis on Guidance and Counselling and Vocational education which ensured that graduates at every level have some scientific and practical knowledge that can be utilized for self-employment, salaried employment or further training (Republic of Kenya, 1984). Nigeria is also among the League of Nations revamping her formal Guidance and Counselling and Vocational education programmes at all levels through the activities of intervention agencies such as Education Trust Fund (ETF).

Despite the importance of Guidance and Counselling and Vocational education in the economic development of nations, people still have different perspectives about its goals. International comparisons show that employers in the united States of America and United Kingdom believe the present state of Guidance and Counselling and Vocational education in their respective countries is inadequate to train students effectively for the changing demands of the work place (Brown \& Keep, 1999; Distler, 1992), Australian employers however, seem satisfied with their Guidance and Counselling and Vocational education system (Fair-Weather, 1999). Also, Malaysian employers and educators expressed satisfaction over the contribution of Guidance and Counselling and Vocational education to the economic development of Malaysia (Denga \& Akinboye, 2002). These evidences were obtained from studies carried out in Europe, America and Asia. Therefore, the problem of this study, posed as a question is: What are the perceptions of employers regarding the role of Guidance and Counselling and Vocational education in sustainable development in Nigeria?

\section{Purpose of the study}

The purpose of this study was to investigate the perceptions of employers regarding the role of Guidance and Counselling and Vocational education in sustainable development in Nigeria. Specifically the study intended to:

1. Investigate the perceptions of employers regarding the contributions of Guidance and Counselling and Vocational education to sustainable development of Nigeria.

2. Evaluate the perceptions of employers regarding the employability of graduates of Guidance and Counselling and Vocational education programmes.

3. Determine if there are differences between the opinions of indigenous and multinational employers regarding the contribution of Guidance and Counselling and Vocational education to sustainable development of Nigeria as well as the employability of Guidance and Counselling and Vocational education graduates.

\section{Research Questions}

The following research questions guided the study:

1. What are the perceptions of employers regarding the contributions of Guidance and Counselling and Vocational education to the sustainable development of Nigeria?

2. What are the perceptions of employers regarding the employability of graduates of Guidance and Counselling and Vocational education programmes?

\section{Hypotheses}

The study also tested the following hypotheses at 0.05 level of confidence.

Ho1: $\quad$ There is no significant difference between the mean responses of indigenous and multinational employers regarding the contributions of Guidance and Counselling and Vocational Education to the sustainable development of Nigeria.

Ho2: $\quad$ There is no significant difference between the mean responses of indigenous and multinational employers regarding the employability of graduates of Guidance and Counselling and Vocational education programmes.

\section{Methodology}

The study used the descriptive survey design. According to Gall, et al (1996), descriptive research involves providing careful descriptions of a phenomenon. Its purpose is to generate accurate description of an event, attitude or behaviour. 
The study was carried out in the south-south geopolitical zone of Nigeria comprising Akwa lbom, Bayelsa, Cross River, Delta, Edo and Rivers States using a descriptive survey design. The choice of this area was informed by the concentration of medium and large size industries in the oil and gas sector of the economy; noting that this sector is the mainstream of the Nigerian economy.

A pilot study carried out to determine the number of industries in the area relevant to this study revealed a total of 59 industries (33 indigenous and 26 multi-nationals). These industries were limited to the categories of oil/gas exploration, civil construction works, oil/gas equipment servicing, fabricated metal and plastic products, machinery manufacturing, and equipment/material haulage.

The industrial categories were chosen based on the assumption that the majority of Guidance and Counselling and Vocational education graduates were employed in these industries. The corporate management personnel of these industries constituted the population of the study. In each of the industries, three management staff categories (personnel managers, production/technical managers and supervisors) were purposively sampled for survey, giving a total sample of 168 employers (80 indigenous and 68 multinationals). These management personnel were assumed to have regular contact with the employees. As such, they were in a unique position to evaluate the employees.

The Guidance and Counselling and Vocational education Role in Sustainable Development Questionnaire (GCVERSDQ), developed by the researcher was used to solicit information from the subjects. The GCVERSDQ items were generated based on the research questions and hypotheses posited for the study. The first section of the GCVERSDQ contained purpose statement, direction on how to respond to the instrument and demographic information of employers. The demographic information included present positions, highest qualification, years of management experience, company size and type of ownership. The second section was a 15 five-point Likert scale items of Strongly Agree, Agree, Undecided, Disagree and Strongly Disagree with corresponding numerical values of 5, 4, 3, 2 and 1 respectively.

The GCVERSDQ was face and content validated by three lecturers in Guidance and Counselling and Vocational education in University of Port Harcourt, Rivers State University of Science and Technology, Port Harcourt, and Niger Delta University, Amassoma, Bayelsa State of Nigeria. The instrument was also pilot tested on 17 subjects who were not part of the sample. The internal consistency reliability for the instrument, using Crobbach's Coefficient Alpha yielded 0.81. Therefore, the final version of the instrument was considered to possess an adequate degree of content and face validity as well as reliability.

A total of 168 copies of GCVERSDQ were administered directly to the respondents by the researcher and three assistants. Each copy of the instrument was accompanied with a cover letter that explained the purpose and importance of the study and also solicited their cooperation. A total of 156 instruments ( 80 indigenous employers' instruments and 68 multinational employers' instruments) were duly completed and returned.

Descriptive and inferential statistics were used to organize, analyze and interpret the data. Mean and standard deviation were the descriptive statistics used to answer the research questions posed in the study. Each GCVERSDQ item was accepted as "Agree", if mean value was greater than or equal to 3.50. Where mean value was equal to 2.50 but less than 3.50, the GCVERSDQ item was regarded as "Undecided". A GCVERSDQ item was regarded as "Disagree" if mean value is less than 2.50. T-test inferential statistics for large independent samples where $\mathrm{N}$ is greater than 30 , as suggested by Denga (1987) and Nworgu (1991), was used to analyze and interpret the hypotheses.

\section{Results}

The findings of the study based on the research questions and hypotheses are presented in the tables below:

\section{Research Question 1}

What are the perceptions of employers regarding the contribution of Guidance and Counselling and Vocational education on the sustainable development of Nigeria?

Table 1: Respondents' views on the contribution of Guidance and Counselling and Vocational education to sustainable development of Nigeria

\begin{tabular}{|l|l|l|l|l|}
\hline S/No & Item & $\bar{X}$ & SD & Decision \\
\hline 1 & Guidance and Counselling and Vocational education institutions have & 2.45 & 1.19 & Disagree \\
\hline
\end{tabular}




\begin{tabular}{|l|l|l|l|l|}
\hline & $\begin{array}{l}\text { prepared sufficient skilled workers to satisfy the needs of Nigeria's } \\
\text { work force }\end{array}$ & & \\
\hline 2 & $\begin{array}{l}\text { Guidance and Counselling and Vocational education institutions have } \\
\text { prepared sufficient semi-skilled workers to satisfy the needs of } \\
\text { Nigeria's workforce }\end{array}$ & 2.37 & 1.19 & Disagree \\
\hline 3 & $\begin{array}{l}\text { Guidance and Counselling and Vocational education institutions are } \\
\text { more suitable than regular academic school programmes in } \\
\text { responding to the rapidly changing nature of skills }\end{array}$ & 3.17 & 1.32 & Undecided \\
\hline 4 & $\begin{array}{l}\text { Guidance and Counselling and Vocational education institutions are } \\
\text { more suitable than regular academic school programmes in } \\
\text { responding to new technology }\end{array}$ & 3.20 & 1.33 & Undecided \\
\hline 5 & $\begin{array}{l}\text { Guidance and Counselling and Vocational education has reduced } \\
\text { unemployment rate in Nigeria }\end{array}$ & 2.00 & 1.21 & Undecided \\
\hline 6 & Guidance and Counselling and Vocational education has reduced & 2.56 & 1.21 & \\
\hline
\end{tabular}

From item 1 through 6 address research question 1. The results in table 1 shows that the respondents were undecided with items 3,4 and 6 , with mean ratings of $3.17(S D=1.32), 3.20(S D=1.33)$ and $2.56(S D=1.21)$ respectively. They disagreed with items 1, 2, and 5. These have mean ratings and standard deviations of $2.45(S D=1.19), 2.37(S D=1.19)$ and $2.00(\mathrm{SD}=1.21)$. With a grand mean of 2.63 , the result shows that employers seem to have a negative perception of the contributions of Counselling and Vocational education to the sustainable development of Nigeria.

\section{Research Questions 2}

What are the perceptions of employers regarding the employability of graduates of Guidance and Counselling and Vocational education programmes?

Table 2: Respondents' views on the employability of Guidance and Counselling and Vocational education graduates

\begin{tabular}{|l|l|l|l|l|}
\hline S/No & Item & $\bar{X}$ & SD & Decision \\
\hline 7 & $\begin{array}{l}\text { Guidance and Counselling and Vocational education } \\
\text { graduates are well prepared to enter the competitive } \\
\text { workforce }\end{array}$ & 2.19 & 1.15 & Disagree \\
\hline 8 & $\begin{array}{l}\text { Guidance and Counselling and Vocational education } \\
\text { graduates are well prepared to be self reliant }\end{array}$ & 1.86 & 0.73 & Disagree \\
\hline 9 & $\begin{array}{l}\text { Guidance and Counselling and Vocational education } \\
\text { graduates have better employment opportunities than } \\
\text { graduates from academic backgrounds }\end{array}$ & 3.13 & 1.24 & $\begin{array}{l}\text { Strongly } \\
\text { Disagree }\end{array}$ \\
\hline 10 & $\begin{array}{l}\text { Guidance and Counselling and Vocational education } \\
\text { graduates are self motivated }\end{array}$ & 3.82 & 1.07 & Agree \\
\hline 11 & $\begin{array}{l}\text { Guidance and Counselling and Vocational education } \\
\text { graduates possess necessary social and interpersonal skills }\end{array}$ & 3.30 & 1.12 & $\begin{array}{l}\text { Strongly } \\
\text { Disagree }\end{array}$ \\
\hline 12 & $\begin{array}{l}\text { Guidance and Counselling and Vocational education } \\
\text { graduates possess necessary communication skills }\end{array}$ & 3.56 & 173.00 & Agree \\
\hline 13 & $\begin{array}{l}\text { Guidance and Counselling and Vocational education } \\
\text { graduates have entrepreneurial skills }\end{array}$ & 2.25 & 1.15 & Disagree \\
\hline 14 & $\begin{array}{l}\text { Guidance and Counselling and Vocational education } \\
\text { graduates possess good attitude towards work }\end{array}$ & 3.67 & 1.19 & Agree \\
\hline 15 & $\begin{array}{l}\text { Guidance and Counselling and Vocational education } \\
\text { graduates possess necessary critical thinking skills }\end{array}$ & 3.24 & 1.26 & $\begin{array}{l}\text { Strongly } \\
\text { Disagree }\end{array}$ \\
\hline 16 & $\begin{array}{l}\text { Guidance and Counselling and Vocational education } \\
\text { graduates possess necessary problem-solving skills }\end{array}$ & 3.06 & 1.33 & $\begin{array}{l}\text { Strongly } \\
\text { Disagree }\end{array}$ \\
\hline & Grand Mean & 2.94 & & \\
\hline
\end{tabular}


Research question 2 was addressed with items 7 through 16 (Table 2). In Table 2, the respondents agreed with items 11 $(\bar{X}=3.82, \mathrm{SD}=1.07)$ and item $14(\bar{X}=3.67, \mathrm{SD}=1.19)$. They were undecided on four items, namely; items 9,11 , 15 , and 16 with mean ratings and standard deviation of $3.13(S D=1.24) 3.30(S D=1.12), 3.23(S D=1.26)$ and 3.06 (SD $=1.33$ ) ratings of $2.19(\mathrm{SD}=1.15), 2.21(\mathrm{SD}=1.12), 1.86(\mathrm{SD}=0.73)$ and $2.25(\mathrm{SD}=1.15)$. The grand mean of 2.94 indicates that the respondents seem to have unfavourable perception on the employability of Guidance and Counselling and Vocational education graduates in Nigeria.

Ho1: $\quad$ There is no significant difference between the mean responses of indigenous and multinational employers regarding the contributions of Guidance and Counselling and Vocational Education to the sustainable development of Nigeria.

The results in Table 3 show that 80 indigenous employers had a mean rating of $2.70(S D=1.29)$ while the 68 multinational employers had a mean rating of $2.54(\mathrm{SD}=1.18)$ yielding a calculated t-value of 0.81 . Since the calculated tvalue (0.81) is less than the critical t-value (1.96) at $\mathrm{df}=154$ and 0.05 level of confidence, the null hypothesis was, therefore accepted.

Table 3: t-test analysis of the response of indigenous and multinational employers regarding Guidance and Counselling and Vocational education contributions to sustainable development of Nigeria

\begin{tabular}{|c|c|c|c|c|c|c|c|c|}
\hline Variable & $\mathrm{N}$ & $X$ & SD & A & $\overline{D f}$ & t-cal & t-crit & Decision \\
\hline Indigenous Employers & 84 & 2.7 & 1.29 & 0.05 & 154 & 0.81 & 1.96 & Not Significant \\
\hline Multinational Employers & 72 & 2.54 & 1.18 & & & & & \\
\hline
\end{tabular}

Finally, the result is that there is no significant difference in the opinion of indigenous and multinational employers regarding the contribution of Guidance and Counselling and Vocational education to sustainable development in Nigeria.

Ho2: $\quad$ There is no significant difference between the mean responses of indigenous and multinational employers regarding the employability of graduates of Guidance and Counselling and Vocational education programmes.

Table 4: t-test analysis of the response of indigenous and multinational employers regarding the employability of Guidance and Counselling and Vocational education graduates

\begin{tabular}{lcccccccl}
\hline Variable & $\mathrm{N}$ & $\bar{X}$ & $\mathrm{SD}$ & $\mathrm{A}$ & $\mathrm{Df}$ & $\mathrm{t}$-cal & t-crit & Decision \\
\hline Indigenous Employers & 84 & 3.01 & 1.23 & 0.05 & 154 & 0.84 & 1.96 & Not Significant \\
$\begin{array}{l}\text { Multinational } \\
\text { Employers }\end{array}$ & 72 & 2.85 & 1.13 & & & & & \\
\hline
\end{tabular}

Table 4 reveals that 84 indigenous employers had a mean rating of $3.01(S D=1.23)$ and the 72 multinational employers a mean rating of 2.85 (1.13) yielding a calculated t-value of 0.84 . The calculated t-value of 0.84 is less than the critical tvalue (1.96) at $\mathrm{df}=154$ and 0.05 level of significance. The second null hypothesis was therefore accepted. The implication of this result is that both indigenous and multinational employers hold the same negative opinion regarding the employability of Guidance and Counselling and Vocational education graduates.

\section{Discussion}

From the data presented in Table 1, it is safe to conclude that Nigerian employers are not satisfied with the Guidance and Counselling and Vocational education system in Nigeria. They maintain that the present Guidance and Counselling and Vocational education programmes have not prepared sufficient skilled and semi-skilled workers to satisfy the needs of 
Nigeria's workforce. This finding is consistent with the perception of U.S. and UK employers (Brown \& Keep, 1999) who believed that the state of Guidance and Counselling and Vocational education in their respective countries is inadequate to train students effectively for the changing demands of the work place. However, the findings negate Ake (2006), and Mustapha and Greenan (2002) who reported that Australian and Malaysian employers respectively are satisfied with their Guidance and Counselling and Vocational education system. Furthermore, it was revealed that Guidance and Counselling and Vocational education has not reduced unemployment in Nigeria.

The implication of these findings is worrisome as the nation may continue to witness imbalance in skill development and production for sustainable national development unless steps are urgently taken to address the situation. With low presence of Guidance and Counselling and Vocational education graduates in the Nigerian economy, developmental changes and innovations brought about by technological advancement and globalization process will remain elusive to the nation. Also, human growth and survival will not be guaranteed. Furthermore, unemployment and crime rates will remain social problems as a result of a greater population of the citizenry possessing non-saleable skills. Based on the foregoing, there is an urgent demand on the Federal Government of Nigeria to set up efforts to upgrade the quality of Guidance and Counselling and Vocational education for sustainable development.

In terms of the employability of Guidance and Counselling and Vocational education graduates, employers in Nigeria believed that Guidance and Counselling and Vocational education graduates are not well prepared to enter the competitive workplace and do not posses enough technical skills in their specialization. These findings contradict the opinions of Malaysian employers (Denga \& Akinboye, 2002) who believed that the graduates of Guidance and Counselling and Vocational education programmes in their country possess more than adequate technical skills. Furthermore the respondents were less satisfied with entrepreneurial skills of the Guidance and Counselling and Vocational education graduates. These findings connote that Nigeria is far from being self-reliant as the major stakeholders in the production process may continued $t$ depend on foreign skilled manpower for technological and economic development. This in turn will adversely affect the foreign exchange earning of the nation. The state of these findings suggests that technical and entrepreneurial skills that could prepare the student to be relevant to the industries and become self-reliant should be full integrated into Guidance and Counselling and Vocational education programmers.

\section{Conclusion}

The present study evaluated the role of Guidance and Counselling and Vocational education in sustainable development in Nigeria as perceived by employers of labour. The study revealed that much needed to be done for the Guidance and Counselling and Vocational education programmes to play its leading role in the industrialization of the nation. Guidance and Counselling and Vocational education has the potential of providing technical skills and job oriented behaviours for individual's sustainable life. Apart from the individual being a prime beneficiary of Guidance and Counselling and Vocational Education, the nation also is a fundamental recipient of Guidance and Counselling and Vocational Education. This is because Guidance and Counselling and Vocational education increases productivity by making economic, efficient and effective use of resources thus, helping in raising the standard of living of the citizenry. For Nigeria to address her socio-economic and technological needs and thereby survive in the modern world, her Guidance and Counselling and Vocational education programmes must definitely be given a new outlook in line with current global trends.

\section{Recommendations}

As a result of the findings of this study and discussions, the following recommendations were made:

- The federal, state and local governments should provide a clear vision and mission for Guidance and Counselling and Vocational education in Nigeria. They should also increase funding of Guidance and Counselling and Vocational education programmes at all levels.

- Government should partner with the private sector to maintain and expand Guidance and Counselling and Vocational education programmes in Nigeria. This could be in form of providing effective leadership and incentives to the private sector to encourage partnership and collaboration with Guidance and Counselling and Vocational education institutions.

Finally, youths should be encouraged through scholarship to enroll into Guidance and Counselling and Vocational education programmes and a balanced approach should be emphasized in the integration of technical applicability and entrepreneurial skills in Guidance and Counselling and Vocational Education. 


\section{References}

Akinboye, J. O. (2004). Guidance and Counselling education (GCE) in Nigeria. The way forward. Paper presented at the $4^{\text {th }}$ annual conference of the Association of Encouraging Qualitative Education in Nigeria, (ASSENQEN) Calabar, Nigeria.

Ake, (2006). Educational, measurement, continuous assessment and psychological testing. Rapid Educational Publishers Limited, Calabar, Nigeria.

Arokoyu, S. B. (2004). Sustainability and sustainable development. In S. B. Arokoyu; O. S. Nwosu; V. U. Dienye and M. Ifeanacho (Eds.), Perspectives on world issues and problems. P. 17 - 26. Amethyst \& Colleagues Publishers, Port Harcourt.

Awokoye, S. O. (1990). Perspectives of quantities and qualities in Nigerian education. A synthetic report of Baganda seminar. Baganda Nigeria Education Research Council.

Brown, A. and Keep, E. (1999, September 22). A U K perspective on how well initial vocation education and training facilities lifelong learning. Paper presented at the European conference on educational research, Lahti Finland.

Denga, D. I. (2005). Measurement and Evaluation. Rapid Educational Publishers Limited, Calabar, Nigeria.

Denga, D. I. (2002). The eve of the $21^{\text {st }}$ century. Educational threshold strategies for entry and sustainable development. Rapid Educational Publishers Limited, Calabar, Nigeria.

Federal Republic of Nigeria (2004). The national policy on education. NERDC Press, Lagos, Nigeria.

Gall, M. D.., Borg, W. R. and Gall, J. P. (1999). Educational research: An introduction. Longman, New York.

Manifred, T and Jennifer, W. (2004). Vocational education and training: Key to the future. Colibri Limited, Greece.

Okolocha, C. C. (2006). Vocational education in Nigeria: Challenges and the way forward. Unizik Orient Journal of education, 2(1), 180189.

Okwelle, C. P. and Urang, E. (2006). Approaches for repositioning rural schools for sustaining development in rural areas. Education Reposition. 1, 13-17.

Republic of Kenya (1984). Ministry of education, science and technology: 8-4-4 system of education. Government Printers, Nairobi. World Commission on Environmental and Development (WCED) (1987). Our common future. Oxford University Press, Oxford. 